Maurer School of Law: Indiana University

Digital Repository @ Maurer Law

\title{
8-2012
}

\section{Religion, Government, and Law in the Contemporary United States}

Daniel O. Conkle

Indiana University Maurer School of Law, conkle@indiana.edu

Follow this and additional works at: https://www.repository.law.indiana.edu/facpub

Part of the Constitutional Law Commons, First Amendment Commons, and the Religion Law

Commons

\section{Recommended Citation}

Conkle, Daniel O., "Religion, Government, and Law in the Contemporary United States" (2012). Articles by Maurer Faculty. 840.

https://www.repository.law.indiana.edu/facpub/840

This Article is brought to you for free and open access by the Faculty Scholarship at Digital Repository @ Maurer Law. It has been accepted for inclusion in Articles by Maurer Faculty by an authorized administrator of Digital Repository @ Maurer Law. For more information, please contact rvaughan@indiana.edu. 


\title{
RELIGION, GOVERNMENT, AND LAW IN THE CONTEMPORARY UNITED STATES
}

\author{
DANIEL O. CONKLE
}

In two decisions of the I940s, Cantwell v. Connecticut ${ }^{\mathrm{I}}$ and Everson v. Board of Education, ${ }^{2}$ the Supreme Court foreshadowed the dominant role that it would play in defining the relationship between religion and government in the contemporary United States. In these cases, the court offered new and important interpretations of the religion clauses of the First Amendment (the Establishment and Free Exercise clauses), which state that "Congress shall make no law respecting an establishment of religion, or prohibiting the free exercise thereof." Notably, the court ruled that these provisions, applicable by their terms only to the federal government, henceforth would be applied to the states as well, including their local subdivisions. In so holding, the court concluded that the Fourteenth Amendment, which explicitly addresses the states, incorporated the First Amendment's religion clauses by reference. The court earlier had ruled likewise concerning the First Amendment's free speech provisions, meaning that after Cantwell and Everson, the states effectively were bound by the First Amendment no less than the federal government.

Cantwell, decided in I940, protected the right of Jehovah's Witnesses to promote their faith through sidewalk evangelism and soliciting in a heavily Roman Catholic neighborhood, even though their appeals included provocative and strongly worded attacks on the Catholic religion. Invalidating the Connecticut laws under which the defendants had been convicted, the Supreme Court cited not only the Free Exercise Clause, which specifically addresses religion, but also the Free Speech Clause, which more generally forbids laws that "abridg[e] the freedom of speech." Cantwell set the stage for a series of Supreme Court decisions addressing questions of religious liberty, especially the liberty of religious minorities, in cases arising under the Free Exercise and Free Speech clauses.

\footnotetext{
I 310 U.S. 296 (I940).

2330 U.S. I (I947).
} 
In the court's 1947 decision in Everson, by contrast, the question was whether the government had gone too far in the other direction, promoting religion to the point of creating a forbidden establishment. The first of many modern cases challenging financial aid programs, Everson narrowly approved a state and local program of bus-fare reimbursement that extended to children attending Roman Catholic schools. Even so, in an often-quoted and influential passage, the court announced a broad and strongly separationist interpretation of the Establishment Clause:

Neither a state nor the Federal Government can set up a church. Neither can pass laws which aid one religion, aid all religions, or prefer one religion over another.... No tax in any amount, large or small, can be levied to support any religious activities or institutions, whatever they may be called, or whatever form they may adopt to teach or practice religion.... In the words of Jefferson, the clause against establishment of religion by law was intended to erect "a wall of separation between church and State."

In a long line of subsequent decisions, the court has addressed Establishment Clause challenges in a variety of contexts. In some cases the court has vigorously enforced the "wall of separation," but in others it has permitted a considerable degree of church-state interaction.

More generally, the Supreme Court's interpretations of the First Amendment have evolved since the I940s, in part as the result of broader religious, cultural, and political developments. In terms of religious controversies, the decade of the I950s was relatively quiet for the court, as for the country. But beginning in the turbulent I960s and continuing into the I980s, the court tended toward aggressive interpretations of the religion clauses. It suggested that the religion clauses might demand a capacious definition of religion, one that encompasses nontheistic moral perspectives. Further, its interpretations offered distinctive constitutional protection to religious free exercise and often demanded a strict separation of church and state. More recently, by contrast, in the continuing wake of the Reagan revolution, the Supreme Court has embraced more conservative and restrained judicial sensibilities. As a result, it has adopted more relaxed constitutional standards. The court has continued to invalidate laws that discriminate against or in favor of religion, either in imposing regulatory burdens or in conferring tangible or symbolic benefits. But it increasingly has upheld nondiscriminatory laws that proceed "neutrally" with respect to religion, even if the laws, in actual operation, have the effect of imposing a burden or conferring a benefit on religious practices.

This essay begins by addressing the Supreme Court's attempts to provide a legal definition of religion. It then discusses the court's wavering

${ }^{3}$ Id. at I5-16. 
path of decisions confronting the issues introduced by Cantwell - the protection of religious exercise and religious speech - along with congressional attempts to "restore" religious freedom after the court repudiated earlier constitutional standards. Thereafter, the essay turns to Establishment Clause developments since Everson, including Supreme Court decisions concerning religion and the public schools, religious symbolism in other settings, and financial aid to religious schools and organizations. It also discusses related political developments, including, for example, the "Faith-Based Initiative" of President George W. Bush. In addressing these various issues, the essay focuses on the direct intersection of religion and law in the contemporary United States. ${ }^{4}$ In closing, however, the essay briefly highlights a range of broader legal and political developments and notes their relationship to the Supreme Court's First Amendment rulings.

\section{DEFINING “RELIGION”}

In earlier historical periods, the "religion" of the religion clauses seemingly was confined to theistic perspectives, and Christianity in particular appeared to have special constitutional status. Religion entailed duties owed to God, nothing more and nothing less. And it was broadly understood that one form of theism, Christianity, was entitled to political and legal support as the favored, if not established, religion. Justice Joseph Story captured the general sentiment of the Founders: "that Christianity ought to receive encouragement from the state, so far as was not incompatible with the private rights of conscience, and the freedom of religious worship. An attempt to level all religions ... would have created universal disapprobation, if not universal indignation." A similar understanding prevailed throughout the nineteenth century and well into the twentieth. In I892, for example, on the basis of its survey of American law and culture, the Supreme Court declared that "this is a Christian nation." And some forty years later, in I93 I, the court officially reaffirmed that "we are a Christian people." 7

This sort of language soon disappeared from judicial opinions, however, and there was in the twentieth century a gradual but dramatic shift of

\footnotetext{
${ }^{4}$ In so doing, the essay draws upon the author's more comprehensive discussion and legal analysis in Daniel O. Conkle, Constitutional Law: The Religion Clauses, 2nd ed. (New York, 2009).

${ }^{5}$ Joseph Story, Commentaries on the Constitution of the United States, 5th ed. (Boston, I891), vol. 2 (I874), 630-I.

${ }^{6}$ Church of the Holy Trinity v. United States, I 43 U.S. 457, 47 I (I 892).

${ }^{7}$ United States v. MacIntosh, 283 U.S. 605, 625 (I93I).
} 
thinking. Driven by changing religious demographics and evolving values, the American understanding of religious liberty eventually rejected the idea of legally sanctioned Christian dominance, embracing instead a vigorous requirement of equality between and among all religions. Beyond that, the very concept of "religion" was tested by America's ever-expanding religious and moral pluralism.

The Supreme Court confronted these new realities in a 1965 case, decided in the midst of the Vietnam War, which included a compulsory military draft. In United States $v$. Seeger, ${ }^{8}$ the court interpreted a statutory religious liberty provision that protected religious objectors to military service. In its definition of religion, the statute referred to "an individual's belief in a relation to a Supreme Being involving duties superior to those arising from any human relation, but [not including] essentially political, sociological, or philosophical views or a merely personal moral code." To earlier generations, this definition would have seemed entirely unexceptional. But by 1965, it seemed problematic - so much so that the court saw fit to rewrite the definition, through creative statutory interpretation, to include any "sincere and meaningful" belief that "occupies a place in the life of its possessor parallel to that filled by the orthodox belief in God of one who clearly qualifies for the exemption." So understood, the definition included the beliefs of a conscientious objector who acknowledged his skepticism concerning the existence of God but who claimed a "belief in and devotion to goodness and virtue for their own sakes, and a religious faith in a purely ethical creed." Indeed, as the court held in a later decision, the definition likewise extended to an objector who had stricken the word "religious" from his application and who had declared that his beliefs were not religious in any conventional sense. ${ }^{10}$

Seeger's expansive, "parallel position" understanding of religion - an understanding that included deeply held moral beliefs that were not theistic - reflected the rapidly changing character of religion in the United States. As the court observed, American religion was remarkably diverse by the I960s, and it extended well beyond the traditional confines of Christianity and Judaism. Perhaps more important, modern theology was transforming certain strands of the traditional faiths themselves. The court noted, for example, that the Protestant theologian Paul Tillich had concluded that God should no longer be understood "as a projection 'out there' or beyond the skies but as the ground of our very being." And "if that word [God] has not much meaning for you," Tillich explained, "translate it, and

\footnotetext{
8380 U.S. 163 (1965).

${ }^{9}$ Id. at $\mathrm{I} 66$.

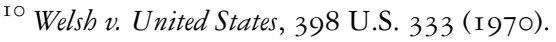


speak of the depths of your life, and the source of your being, of your ultimate concern, of what you take seriously without any reservation." Ir

Although influenced by constitutional considerations, Seeger rested on statutory, not constitutional, interpretation. In subsequent decisions, the Supreme Court sometimes has suggested that it might adopt a more narrow approach in other legal contexts. Indeed, an overly broad constitutional definition of religion could render religious liberty unmanageable in an era of pervasive government, because the government, of necessity, frequently burdens or favors particular moral perspectives. Even so, the Seeger definition may be fitting at least for the Free Exercise Clause, which addresses claims of constitutional protection for conscience-based acts or abstentions. In fact, since the I960s we have seen an ever-increasing religious and moral diversity in the United States, both within and outside the traditional religious faiths, arguably making the court's reasoning in Seeger even more compelling today.

In any event, it is quite clear that the religion clauses' core protection of belief and profession (as opposed to conscience-driven acts or abstentions) today reaches well beyond its historical boundaries. In a 1985 decision, the court explained the contemporary scope of an individual's "freedom to choose his own creed" and "his right to refrain from accepting the creed established by the majority."

At one time it was thought that this right merely proscribed the preference of one Christian sect over another, but would not require equal respect for the conscience of the infidel, the atheist, or the adherent of a non-Christian faith such as Islam or Judaism. But when the underlying principle has been examined in the crucible of litigation, the Court has unambiguously concluded that the individual freedom of conscience protected by the First Amendment embraces the right to select any religious faith or none at all. ${ }^{12}$

As society changes, so does the law. And the realm of religion and conscience that is respected and valued in contemporary America - in law and society alike - plainly is not confined to past understandings.

\section{FREE EXERCISE AND FREEDOM OF SPEECH}

From the I960s to the present, the United States has witnessed the rise, fall, and partial reinstatement of vigorous legal protection for the free exercise of religion. Building upon its I 940 decision in Cantwell, the Supreme

${ }^{\text {II }}$ Seeger, 380 U.S. at I80, I87, quoting Paul Tillich, The Shaking of the Foundations (New York, I948), 57.

${ }^{\text {I } 2}$ Wallace v. Jaffree, 472 U.S. 38, 52-3 (1985). 
Court interpreted the Free Exercise Clause expansively in the I960s and I970s. The court later changed course, and its I990 decision in Employment Division v. Smith ${ }^{\mathrm{I}}$ dramatically curtailed the constitutional protection that had previously been in place. Congress responded to Smith with a pair of important religious liberty statutes, thereby restoring a measure of protection for religiously motivated conduct. In addition, the Supreme Court itself, despite Smith, has increasingly protected one important component of religious freedom, religious speech, through its interpretations of the Free Speech Clause.

\section{THE FREE EXERCISE CLAUSE}

The Supreme Court's decisions interpreting the Free Exercise Clause typically have involved religion in a conventional and indisputable sense, obviating the need for definitional discussions of the sort undertaken in Seeger. Instead, the court generally has focused on the scope of the clause when it is conceded that religion is at stake. As already suggested, the contemporary Free Exercise Clause protects, at a minimum, the freedom to believe or disbelieve, and to profess or not, as one sees fit. Accordingly, religious tests or oaths cannot be required for state officeholders, just as they are banned at the federal level by the explicit command of Article VI of the original Constitution. As the court explained in its I961 decision in Torcaso v. Watkins, ${ }^{14}$ "neither a State nor the Federal Government can constitutionally force a person 'to profess a belief or disbelief in any religion."' 15 This much today is uncontested and uncontroversial. But what about religious conduct, that is, religiously motivated acts or abstentions going beyond mere profession? Is such conduct protected by the Free Exercise Clause even in the face of legal prohibitions or restrictions? This has been the main point of contention in contemporary debates concerning the clause. It is a question of fundamental importance in our increasingly pluralistic society, especially for religious minorities whose practices may be deliberately or inadvertently impaired by the law, which tends to reflect conventional, majoritarian sentiments.

In early cases, the Supreme Court suggested that the Free Exercise Clause offers no protection for religious conduct, apart from religious profession or speech. Thus, in its 1879 decision in Reynolds v. United States ${ }^{16}$ the court held that the clause did not protect the Mormon practice of polygamy.

${ }^{13} 494$ U.S. 872 (I990).

${ }^{14}{ }_{3} 67$ U.S. 488 (I96I).

${ }^{15}$ Id. at 495 .

${ }^{\text {I}} 98$ U.S. I 45 ( 1879 ). 
"Laws are made for the government of actions," the court wrote, "and while they cannot interfere with mere religious belief and opinions, they may with practices," lest "every citizen ... become a law unto himself." ${ }^{17}$ In the I96os, by contrast, the Supreme Court rejected this restrictive approach and interpreted the Free Exercise Clause to protect religious conduct, that is, acts or abstentions that are sincerely motivated by religious beliefs. The court recognized that religious conduct, unlike mere belief, cannot be absolutely protected, but it ruled that laws substantially burdening religious conduct would be declared unconstitutional unless they were found to serve sufficiently important or (in constitutional parlance) "compelling" governmental interests.

From the I960s through the I980s, the Free Exercise Clause offered protection not only from laws that targeted religious conduct for discriminatory treatment, but also from nondiscriminatory laws of general applicability. If the government could not justify the application of a nondiscriminatory law to religious conduct, an exemption from the law was constitutionally required. This analysis extended not only to laws that made religious conduct illegal, but also to laws that imposed more indirect burdens, burdens that discouraged religious conduct by making it difficult or costly.

The Supreme Court first embraced this expansive interpretation in 1963, in the seminal case of Sherbert $v$. Verner. ${ }^{18}$ South Carolina law made unemployment compensation available only to those who would accept Saturday employment, but the court ruled that the Free Exercise Clause demanded an exemption for a Seventh-Day Adventist. Although the law did not make her religious practice illegal, the court found that it exerted unmistakable pressure on the exercise of religion by offering the claimant a financial incentive to violate her Sabbath. The state contended that it had a "compelling" interest in avoiding fraudulent religious claims, but the court ruled that this did not justify a categorical ban on religious exemptions, even for claimants who were undeniably sincere.

In I972, the Supreme Court issued another important ruling, protecting Old Order Amish from the operation of a compulsory education law that required parents to send their children to school until the age of sixteen. In this case, Wisconsin v. Yoder, ${ }^{19}$ the burden on religious conduct was direct and inescapable. Under threat of criminal sanction, the law required the Amish to abandon a religious obligation: protecting their children from the worldly influences of high school. The court recognized Wisconsin's strong interest in education, but it found that requiring Amish children to

${ }^{17}$ Id. at I66-7.

I8 374 U.S. 398 ( 1963 ).

I9 406 U.S. 205 (1972). 
attend one or two years of high school (they attended elementary school) would do little to serve that interest, especially since the Amish community itself provided an alternative form of education, including informal vocational training. Accordingly, the court ruled that the Amish were entitled to an exemption from the law.

Throughout the I970s and I980s, the Supreme Court continued to endorse the constitutional framework of Sherbert and Yoder. Even so, it rejected a number of free exercise claims in the I980s, setting the stage for the more dramatic judicial retrenchment that would follow. In United States $v$. Lee, ${ }^{20}$ for instance, the court rejected an exemption sought by the Amish from participation in social security, finding that the government's interest in a uniform tax system should prevail. In addition, the court adopted explicit exceptions to the Sherbert/Yoder approach for military and prison regulations. ${ }^{21}$ And it ruled that the Free Exercise Clause did not limit the government's internal operations, including the use of government land, no matter the adverse impact on religious practices. In Lyng v. Northwest Indian Cemetery Protective Association, ${ }^{22}$ for example, the court found no constitutional impediment to a proposed National Forest road that, according to the challengers, would have seriously damaged the sanctity of Native American sacred sites. (The court in Lyng also rejected a claim under the American Indian Religious Freedom Act of 1978, finding that the act confers no enforceable legal rights.) Outside these exceptional contexts, however, the court continued to apply the Sherbert/Yoder framework, and, indeed, it specifically reaffirmed its decision in Sherbert in several comparable cases.

Employment Division v. Smith, decided in 1990 , marked a clear and controversial turn in the Supreme Court's constitutional jurisprudence. In Smith, the court was asked to recognize a free exercise exemption for the sacramental use of an otherwise illegal drug, peyote, by members of the Native American Church. Not only did the court refuse to do so, but, on a five-four vote, it also declined to apply the analysis that Sherbert and Yoder appeared to require. Although the court purported to distinguish and preserve its particular holdings in those and similar cases, it renounced their interpretive underpinnings. Thus, the court declared that nondiscriminatory laws affecting religious conduct do not implicate the Free Exercise Clause, do not require special constitutional justification, and do not require religious exemptions. Giving new life to its century-old decision

\footnotetext{
${ }^{20} 455$ U.S. 252 (I982).

${ }^{21}$ Goldman v. Weinberger, 475 U.S. 503 (I986) (military); O'Lone v. Estate of Shabazz, 482 U.S. 342 (I987) (prisons).

22485 U.S. 439 (1988).
} 
in Reynolds, the court suggested that to grant a religious exemption would be to permit the religious believer, "by virtue of his beliefs, 'to become a law unto himself," a result that "contradicts both constitutional tradition and common sense." 23

Although more complex interpretations of the court's constitutional doctrine are possible, Smith essentially reduced the Free Exercise Clause to a prohibition on deliberate discrimination against religion. Accordingly, a law burdening religious conduct no longer triggers presumptive constitutional protection unless the law targets that conduct for unequal treatment. As interpreted in Smith, the Free Exercise Clause no longer protects religious conscience or voluntarism as an independent value. Instead, it merely ensures a type of formal religious equality.

In the contemporary period, laws that deliberately discriminate against religion are rare, but they are not nonexistent, as became clear in a case decided just three years after Smith. In Church of the Lukumi Babalu Aye, Inc. v. City of Hialeah, ${ }^{24}$ the Supreme Court invalidated a series of ordinances that had been adopted by the City of Hialeah, Florida, in a transparent attempt to stop the establishment and spread of the Santería religion, which practices animal sacrifice as a principal form of devotion. The ordinances effectively outlawed Santería animal sacrifice even as they left other animal killings unaffected. Unlike, for example, a general ban on animal killing (which, under Smith, would raise no free exercise issue), the Hialeah ordinances specifically targeted Santería religious exercise. As a result, the ordinances triggered presumptive constitutional protection and rigorous judicial scrutiny, and they could not survive that review.

\section{CONGRESSIONAL AND STATE-LAW PROTECTIONS OF RELIGIOUS FREEDOM}

Notwithstanding Lukumi, the court's current understanding of the Free Exercise Clause offers far less protection to religious believers, including religious minorities, than did the pre-Smith approach. Some state courts, as a matter of state constitutional law, have rejected the Supreme Court's reasoning and have continued to protect religious conduct from nondiscriminatory laws. In addition, the Supreme Court's restrictive interpretation of the Free Exercise Clause has generated a remarkable series of legislative responses.

In its initial reaction to Smith, Congress concluded that the decision gave inadequate protection to religious freedom and, indeed, that the

\footnotetext{
${ }^{23}$ Employment Division v. Smith, 494 U.S. 872, 885 (I990).

24 508 U.S. 520 (1993).
} 
Supreme Court's interpretation of the Free Exercise Clause was erroneous. Accordingly, Congress attempted to "restore" the legal protection provided by the earlier approach of Sherbert and Yoder, now as a matter of statutory rather than constitutional right. Thus, the Religious Freedom Restoration Act of 1993 (RFRA) declared that "government shall not substantially burden a person's exercise of religion even if the burden results from a rule of general applicability" unless the burden "is in furtherance of a compelling governmental interest." 25 RFRA was supported by a broad coalition of divergent interest groups, ranging from the American Civil Liberties Union to the Southern Baptist Convention, and it was approved in Congress by nearly unanimous votes. But the Supreme Court was not impressed by Congress' attempt effectively to overrule the court, and it responded with a 1997 decision dramatically curtailing the statute's reach. In City of Boerne $v$. Flores ${ }^{26}$ the court ruled that RFRA violated the Constitution because Congress lacked the power to impose the statute's requirements on state and local governments. By contrast, it appears that RFRA remains valid as applied to federal laws and practices. In its 2006 decision in Gonzales v. 0 Centro Espirita Beneficente Uniao do Vegetal, ${ }^{27}$ the Supreme Court not only assumed the constitutionality of RFRA in the federal context, but also offered a vigorous interpretation of the statutory protection that it affords. In so doing, the court unanimously approved an exemption under RFRA for a small religious group, indigenous to Brazil, that uses a sacramental tea containing a hallucinogen otherwise banned by federal law.

In response to Boerne, some state legislatures enacted state-law versions of RFRA to replace the invalidated portion of the federal law. Congress initially considered a broad response of its own, but it ultimately enacted a more limited statute, the Religious Land Use and Institutionalized Persons Act of 2000 (RLUIPA). RLUIPA reimposed federal, RFRA-like provisions on state and local governments, but only for land use regulations and regulations affecting institutionalized persons, including prisoners. ${ }^{28}$ Despite its limited reach, RLUIPA raises significant issues of federalism, but it so far has survived - or avoided - constitutional challenges addressing these concerns.

All of these developments, taken together, mean that the Sherbert/Yoder approach now applies in some legal contexts but not others. It applies to federal laws by virtue of RFRA, and it applies to state laws falling within the selective coverage of RLUIPA. It also applies if a particular state elects

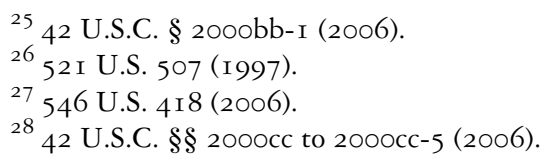


to offer this protection as a matter of state law. Otherwise, the restrictive approach of Smith continues to control, confining the Free Exercise Clause mainly to discriminatory laws.

\section{THE FIRST AMENDMENT AND RELIGIOUS SPEECH}

Despite Smith, the contemporary Supreme Court has interpreted the First Amendment aggressively with respect to one type of religious conduct, religious speech, which it has protected under the Free Speech Clause. Building upon and expanding the free speech component of Cantwell, the court has ruled that private religious speech, including religious worship, is entitled to the same free speech protection as core political speech. And it has extended its distaste for discrimination to the free speech context, issuing a series of rulings granting religious speakers equal access to public property even when the government argues that the separation of church and state demands their exclusion. Notably, these cases often have involved Christian groups, and they have included claims of access to public school buildings. As we will see, the Supreme Court has consistently ruled that the establishment clause forbids public schools to sponsor prayers or religious exercises. But the court also has ruled that private religious groups have the right to use public school buildings, after hours, on the same basis as other private groups. In its I 993 decision in Lamb's Chapel v. Center Moriches Union Free School District, ${ }^{29}$ for example, the court ruled that a public school district, having opened its facilities for after-hours use by various nonreligious groups, could not bar a religious group from presenting a film series promoting "Christian family values."

In a 200 I decision, the court extended its equal access doctrine even to after-school religious meetings for elementary students. In Good News Club v. Milford Central School, ${ }^{3 \circ}$ an evangelical Christian organization requested permission to conduct meetings for elementary school students immediately after school, meetings at which the children would sing songs, hear Bible lessons, memorize scripture, and pray. School policy permitted privately sponsored after-school meetings for various purposes, including morals and character education for children, but it prohibited the use of school facilities "for religious purposes." Citing this prohibition as well as the Establishment Clause, the school denied the organization's request. The Supreme Court ruled that the school's policy, as applied to the proposed meetings, impermissibly discriminated against religious speech in violation of the Free Speech Clause. Contrary to the school's argument, moreover, the

\footnotetext{
${ }^{29} 508$ U.S. 384 (1993).

30533 U.S. 98 (200I).
} 
court found that the policy was not redeemed by the Establishment Clause. The court reasoned that although public schools cannot themselves promote religion, this does not occur when schools merely provide the sort of nondiscriminatory access that the Christian organization was seeking possible misperceptions to the contrary notwithstanding.

The Supreme Court's equal access doctrine offers protection to Christian as well as other religious speakers and groups, and it operates as a limitation on the court's Establishment Clause doctrine. In the equal access context, Christian conservatives, among others, have achieved considerable success by invoking arguments for equal treatment, which resonate strongly in the political and legal culture of the contemporary United States.

\section{THE ESTABLISHMENT CLAUSE: RELIGION AND THE PUBLIC SCHOOLS}

\section{Prayer and Religious Instruction}

Although the Supreme Court's equal access decisions protect privately sponsored religious speech, even in public school buildings, the court has ruled that the Establishment Clause forbids the public schools themselves to sponsor or promote religion. Citing the impressionability of children and their susceptibility to peer pressure and to the influence of teachers and other school officials, the court has aggressively enforced this prohibition, and in this respect the court's stance has been relatively stable throughout the contemporary period. Thus, in a long line of cases from I948 to the present, the Supreme Court has invalidated school-sponsored prayer and religious instruction in the public schools, even when student participation is designated as voluntary. Apart from its aberrational 1952 decision in Zorach v. Clauson, ${ }^{31}$ the court has consistently reasoned that the public schools cannot act to favor Christianity, any other religion, or even religion in general. In so ruling, the court has protected religious minorities and nonbelievers not only from the risk of direct or subtle coercion, but also from feelings of exclusion, affront, and alienation.

The Supreme Court's initial encounter with religion and the public schools occurred in 1948, only a year after Everson v. Board of Education. In Everson, the court had declared that the Establishment Clause forbids the government to aid either one religion or religion in general. In Illinois ex rel. McCollum v. Board of Education, ${ }^{32}$ the court relied on this principle to invalidate a public school program that provided religious instruction

\footnotetext{
${ }^{31} 343$ U.S. 306 (1952).

32333 U.S. 203 (1948).
} 
through a "released-time" arrangement. Under the program, weekly classes in religious instruction, taught by privately employed religious teachers of various faiths, were conducted in the school building during regular school hours. The classes were offered only to students whose parents had requested that they attend; students not attending continued their secular studies. The court noted the challengers' argument that the program was voluntary in name only, and it also noted the fact of compulsory school attendance. But the court did not base its decision on coercion. Instead, the court ruled that the program of religious instruction was unconstitutional because (unlike an equal access program) it singled out religion for special, advantageous treatment, promoting religion over irreligion in violation of the principle announced in Everson.

Four years later, by contrast, the court in Zorach $v$. Clauson upheld a very similar program of religious released time. As in McCollum, the challenged program offered weekly religious instruction during regular school hours to students whose parents requested that they attend. Unlike in McCollum, however, the religious classes were conducted off the premises of the public schools, at religious centers to which the participating students retreated. For the court in Zorach, this made all the difference, because now the public schools were doing "no more than accommodat[ing] their schedules to a program of outside religious instruction." 33 In reality, however, the court's attempt to distinguish McCollum was tenuous, because the Zorach program still promoted religion over irreligion: aided by compulsory attendance laws, the public schools singled out religious instruction, and nothing else, for special, preferential treatment. Nevertheless, and despite later decisions further undermining its premises, Zorach has not been overruled. Some school districts, especially in rural areas, continue to sponsor off-thepremises released-time programs, and such programs are permissible as a matter of prevailing constitutional law.

In the years since Zorach, the Supreme Court has consistently and repeatedly invalidated laws and policies promoting school-sponsored prayers and devotional exercises in the public schools, even if nonsectarian and formally voluntary. In its landmark decisions of 1962 and 1963 , the court addressed the classic form of school-sponsored prayer and devotion: spoken exercises in the classroom. In Engel v. Vitale, ${ }^{34}$ the court struck down a program that called for teachers to lead their students in a daily, state-prescribed prayer. The prayer was brief and nondenominational: "Almighty God, we acknowledge our dependence upon Thee, and we beg Thy blessings upon us, our parents, our teachers and our Country." In addition, the prayer was

${ }^{33}$ Zorach, 343 U.S. at 315.

34 370 U.S. 42 I (1962). 
designated as voluntary; no student who objected was required to participate. Nonetheless, the court invalidated the prayer. And in School District of Abington Township v. Schempp, ${ }^{35}$ the court extended Engel to devotional practices not involving a state-prescribed prayer, including the reading of Bible verses to nonobjecting students and their collective recitation of the Lord's Prayer. Justice Stewart, the sole dissenter in Engel and Schempp, noted that there was no proof of demonstrable coercion in either case. The majority of the court, by contrast, was content to note the risk of "indirect coercive pressure upon religious minorities to conform to the prevailing officially approved religion." 36

Engel and Schempp were enormously controversial decisions, and the controversy has not died. Critics have pushed for a constitutional amendment, but these efforts have failed. Despite ongoing criticism, moreover, the Supreme Court has not only reaffirmed the decisions, but also extended them. It has imposed constitutional limits on moments of silence, and it has precluded school-sponsored prayers even during graduation ceremonies and at extracurricular events, and even when offered by students rather than teachers.

As one response to Engel and Schempp, more than half of the states have adopted statutes authorizing moments of silence in the public schools, moments that may be used by religious students as a time for silent prayer. In its 1985 decision in Wallace v. Jaffree, ${ }^{37}$ however, the court declared that moment-of-silence statutes are unconstitutional if they are purposefully crafted to promote silent prayer. In Wallace, the court invalidated a I98I Alabama statute that authorized a period of classroom silence "for meditation or voluntary prayer." This holding went well beyond Engel and Schempp, but it did not reach all moment-of-silence laws. As the court explained, preexisting Alabama law had already authorized a period of silence "for meditation," and the stark legislative history of the I98 I enactment confirmed that it was "entirely motivated by a purpose to advance religion" by "convey[ing] a message of State endorsement and promotion of prayer." ${ }^{8}$ The court's opinion suggested that a moment-of-silence law not mentioning prayer would be constitutionally permissible. Taking into account the views of five justices who wrote concurring and dissenting opinions, moreover, it appears that the court likewise would have approved a law that did mention prayer as one permissible use for a moment of silence - as long as the law's language and history did not reveal the impermissible purpose of

\footnotetext{
35374 U.S. 203 (1963).

${ }^{36}$ Engel, 370 U.S. at $43 \mathrm{I}$.

${ }^{37} 472$ U.S. 38 (1985).

${ }^{38}$ Id. at 56,59 .
} 
favoring silent prayer over other forms of quiet reflection. In the years since Wallace, lower courts have been left to apply the decision to other momentof-silence laws. There have been mixed results in these cases, but most of the laws have been upheld and remain in place.

After Wallace, the Supreme Court next confronted a school prayer challenge in 1992. Through a series of appointments, Presidents Ronald Reagan and George H. W. Bush had attempted to move the court in a more conservative direction, and there was speculation that the newly constituted court might limit the Establishment Clause to cases involving demonstrable coercion, much as Justice Stewart had urged in Engel and Schempp. In fact, the court in Lee v. Weisman ${ }^{39}$ did utilize a coercion analysis of sorts, but, over the vigorous dissent of four justices, the court nonetheless concluded that it was unconstitutional for a public school to sponsor a clergy-led, nonsectarian prayer at a graduation ceremony. Unlike the dissenting justices, the court took an extremely broad view of illicit governmental coercion. Noting the "subtle coercive pressure" of the public school environment and the role of "public pressure, as well as peer pressure," the court found that the school had placed objecting students in an "untenable position" of "indirect coercion." This coercion did not necessarily induce objecting students to join the prayer, even silently. But it did subject them to "pressure, though subtle and indirect," to "participate" in a more passive way. Thus, they felt obliged to attend the ceremony despite their objection, and, once there, they felt obliged to acquiesce quietly in the prayer, giving others the impression that they were either joining or approving it..$^{4}$

In its 2000 decision in Santa Fe Independent School District v. Doe, ${ }^{41}$ the court applied and extended Weisman, invalidating a school board policy that called for student votes to determine whether there would be a student-led "invocation and/or message" before high school football games, in part "to solemnize" the games. A six-justice majority found that the policy's purpose, as revealed by its text and context, was to preserve and promote the school district's longstanding practice of school-sanctioned prayers at the games. As in Weisman, moreover, the court found indirect and subtle coercion even in the absence of compulsory attendance.

\section{EVOLUTION AND CREATIONISM}

At least since the notorious Scopes trial of the $1920 \mathrm{~S},{ }^{42}$ there has been tremendous controversy concerning the topic of human origins and how it

39505 U.S. 577 (1992).

${ }^{40}$ Id. at $590-9$.

${ }^{4 \mathrm{I}} 530$ U.S. 290 (2000).

${ }^{42}$ See Scopes v. State, 289 S.W. 363 (Tenn. I927). 
should be taught in the public schools. The Supreme Court has declared that the Establishment Clause imposes significant limitations in this context. In essence, the court has treated creationism as a matter of religious instruction, bringing into play the same sort of reasoning that the court has applied to school-sponsored prayer and religious instruction generally. Thus, in its 1968 decision in Epperson v. Arkansas ${ }^{43}$ and its 1987 decision in Edwards v. Aguillard, ${ }^{44}$ the court invalidated laws that were designed to prohibit the teaching of evolution or to promote the teaching of creationism.

In Epperson, the court invalidated an Arkansas law that had been enacted in 1928 , in the aftermath of the Scopes case. As did the Tennessee law at issue in Scopes, the Arkansas law prohibited public school teachers to teach "the theory or doctrine that mankind ascended or descended from a lower order of animals." Focusing on the history of the law, the court concluded that "fundamentalist sectarian conviction was and is the law's reason for existence" and that the law prohibited the teaching of human evolution "for the sole reason that it is deemed to conflict with a particular religious doctrine; that is, with a particular interpretation of the Book of Genesis by a particular religious group." 45 As a result, the law had the unconstitutional purpose of advancing religion, and, indeed, a particular religion, by protecting that religion from competing views.

Going a step beyond Epperson, the court in Edwards invalidated a Louisiana "balanced treatment" statute. The Louisiana statute did not preclude the teaching of evolution, at least not categorically. Rather, it declared that any public school that elected to teach evolution was required to teach "creation science" as well. The state claimed that creation science reflected legitimate scientific opinion that had been improperly repressed, and it contended that the statute permitted students to confront the competing evidence and decide the matter for themselves. Over a vigorous dissent by Justice Scalia, however, the court rejected the state's arguments and concluded that its secular defense of the statute was a "sham." The court noted that public school teachers are free to teach genuinely scientific evidence about human origins, even if this evidence might undermine the prevailing theory of evolution, and it suggested that a legislature would be free to require that the public schools include this type of scientific critique. On the basis of the content of the Louisiana statute and its legislative history, however, the court found that it was not designed to promote the teaching of diverse scientific theories. Rather, the legislation was adopted to advance and endorse a particular religious understanding of creation, an

\footnotetext{
43393 U.S. 97 (1968).

44482 U.S. 578 (I987).

${ }^{45}$ Epperson, 393 U.S. at 103 , I08.
} 
understanding that appeared to be drawn from a literal reading of Genesis. As a result, the law was unconstitutional.

In recent years, a new line of argument has featured the theory of "intelligent design," which contends that evolution and natural selection are inadequate to explain the biological complexity of life, meaning that an intelligent force must be at work. The Supreme Court has not addressed intelligent design, but the issue garnered national attention in 2004 when the school board of Dover, Pennsylvania, adopted a policy requiring that students be informed about this theory in addition to the theory of evolution. In a broadly written decision (which was not appealed), a federal district court invalidated the policy ${ }^{46}$ Although the argument for intelligent design does not track the biblical account of creation, the court concluded that this argument, like that of creation science before it, is nothing more than a veiled attempt to advance a religious understanding of creation. Accordingly, under the reasoning of Epperson and Edwards, the Dover policy was unconstitutional.

\section{THE PLEDGE OF ALLEGIANCE}

Public schools routinely sponsor recitations of the Pledge of Allegiance, through which students recite the following, congressionally prescribed language: "I pledge allegiance to the Flag of the United States of America, and to the Republic for which it stands, one Nation under God, indivisible, with liberty and justice for all." 47 Congress added the "under God" language in 1954, during the Cold War, in part to distinguish the United States from the Soviet Union. Even before this addition, the Supreme Court had ruled in its 1943 decision in West Virginia State Board of Education v.

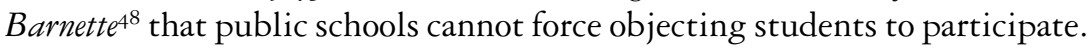
Conversely, it has been widely assumed that schools are free to lead willing students in the pledge. In 2002, however, the U.S. Court of Appeals for the Ninth Circuit, citing the Establishment Clause, ruled that schoolsponsored recitations of the pledge, even if formally voluntary, could no longer include the "under God" language. ${ }^{49}$ The court's holding appeared to follow logically from the Supreme Court's prevailing Establishment Clause jurisprudence, including its school prayer decisions. Even so, the Ninth Circuit's decision triggered a public outcry, including condemnation by political officials of all stripes. The Supreme Court granted review,

\footnotetext{
${ }^{46}$ Kitzmiller v. Dover Area School District, 400 F. Supp. 2d 707 (M.D. Pa. 2005).

474 U.S.C. $\$ 4$ (2006).

48 II9 U.S. 624 (1943).

49 Newdow v. U.S. Congress, 292 F.3d 597 (9th Cir. 2002), amended, 328 F.3d 466 (2003), rev'd, 542 U.S. I (2004).
} 
but the case ended with a whimper when the court avoided a ruling on the merits.

In Elk Grove Unified School District v. Newdow, ${ }^{50}$ the Supreme Court reversed the Ninth Circuit on procedural grounds, concluding that the challenger (a parent with limited and disputed custodial rights) lacked "prudential standing" to bring the case in federal court. In a potentially influential separate opinion, however, Justice O'Connor reached the merits and argued that the "under God" reference is permissible. ${ }^{5 \mathrm{I}}$ Citing the tradition and ubiquity of the pledge, she noted that the "under God" language dates back half a century, and she suggested that its recitation in the public schools has become part of the American social fabric. Distinguishing the court's school prayer decisions, she emphasized that the pledge is not a prayer, and its recitation is not a religious exercise. Rather, it is a patriotic exercise that includes a brief and general religious reference or declaration. As a result, she argued, it is not fatal to the pledge (as it is to a schoolsponsored prayer) that students may feel subtle coercive pressure to participate, as long as the school, in line with Barnette, does not directly compel students to join the recitation, either in full or in part.

The Pledge of Allegiance issue tests the limits of the Establishment Clause in the public school setting. The issue remains unresolved, and it is likely to return to the Supreme Court in the future.

\section{THE ESTABLISHMENT CLAUSE}

\section{Prayer and Religious Symbolism outside the Public School Setting}

Beginning in the I980s, the Supreme Court moved beyond the public schools to consider claims that the government was improperly promoting prayer and religious symbolism in other settings. In theory, the Establishment Clause prohibition is fully applicable here, no less than in the public schools, even though here any risk of coercion may be slight. In practice, however, the court's decisions have followed a wavering path, with the justices issuing mixed results depending on fine distinctions. Mirroring Justice O'Connor's opinion in Newdow, the court sometimes has relied upon tradition. Otherwise, it has focused on the particular governmental practice under review, asking whether that practice, properly understood, acknowledges or recognizes religion for secular reasons or instead conveys an impermissible message of governmental promotion or endorsement, a message that might affront and alienate religious minorities and nonbelievers.

\footnotetext{
50542 U.S. I (2004).

${ }^{5} \mathrm{I}$ Id. at 33-45 (O'Connor, J., concurring in the judgment).
} 
In its 1983 decision in Marsh v. Chambers,,$^{52}$ the first ruling in this context, the Supreme Court invoked tradition to uphold the practice of legislative prayer by publicly paid chaplains. The court emphasized that legislative prayer goes back to the First Congress and is such a longstanding tradition that it is "part of the fabric of our society." 53 On similar grounds, the court has suggested that other longstanding practices are likewise permissible, including, for example, our national motto, "In God We Trust," and the court's own opening cry, "God Save the United States and this Honorable Court."

In other decisions, the court sometimes has alluded to tradition in a more general way, noting the prominent role of religion in American political and governmental history, but its decisions generally have turned on a fact-specific evaluation of the particular practice under review. A year after Marsh, for example, in Lynch v. Donnelly, ${ }^{54}$ the court upheld the use of a nativity scene in a municipal Christmas display that also included a Santa Claus house, reindeer, and other secular symbols. According to the court, the city was simply celebrating Christmas, a public and heavily secularized holiday, by giving recognition to its various traditional symbols. Five years later, however, distinguishing Lynch, the court in County of Allegheny v. $A C L U^{5 s}$ ruled against a stand-alone nativity scene even as it approved a separate display that included a Chanukah menorah, a Christmas tree, and a sign promoting liberty.

More recently, in 2005, the Supreme Court addressed similar issues in highly publicized cases challenging governmental displays of the Ten Commandments. The court once again reached mixed results, focusing on the particular facts at hand. In McCreary County v. ACLU of Kentucky, ${ }^{56}$ a five-justice majority invalidated recently erected courthouse displays of framed copies of the Ten Commandments. The commandments were surrounded by the Magna Carta, the Declaration of Independence, the Bill of Rights, and other historical documents, but the current arrangements had been preceded by earlier, more limited displays that clearly were designed to promote the religious content of the commandments. According to the court, the current displays, developed only in response to litigation, still conveyed the same, predominantly religious message. In Van Orden v. Perry, ${ }^{57}$ by contrast, a different five-justice majority upheld the constitutionality of a forty-year-old display of the Ten Commandments on the outdoor grounds

\footnotetext{
$52{ }_{463}$ U.S. 783 (1983).

53 Id. at 792.

54465 U.S. 668 (1984).

55492 U.S. 573 (1989).

56 545 U.S. 844 (2005).

${ }^{5} 545$ U.S. 677 (2005).
} 
of the Texas State Capitol, where the commandments stood as one monument among many in a large, parklike setting. Switching sides as he cast the deciding vote, Justice Breyer reasoned in his controlling opinion that unlike the displays in McCreary, the Texas monument, in its particular historical context and physical setting, conveyed a predominately secular message - a message about the Ten Commandments' historical significance and their importance to secular morality..$^{8}$

The Supreme Court's nuanced decisions in this area have elicited criticisms from both sides, but they have effected something of a culture-war compromise. Traditional and tempered religious displays may be permitted, but stark endorsements of religion typically are not. As a result, the government can celebrate America's religious heritage and culture to a degree, but religious minorities and nonbelievers are protected from more flagrant affronts to their religious or irreligious sensibilities.

\section{THE ESTABLISHMENT CLAUSE}

\section{Public Aid to Religious Schools and Organizations}

The Supreme Court's seminal Establishment Clause decision from the I940s, Everson v. Board of Education, also was the modern court's first encounter with a public aid controversy. As noted earlier, the court narrowly approved the particular program before it, which extended bus-fare reimbursement to students attending Roman Catholic schools. At the same time, however, the justices used strongly separationist language, signaling that the clause would be construed to impose significant limitations on financial support for religious beneficiaries. The court did not return to the public aid context for twenty years, but, since then, it has considered numerous challenges. Moreover, unlike in its public school and religious symbolism cases, the court's stance in this context has shifted dramatically over time.

In a series of cases in the I970s and I980s, the Supreme Court approved some public aid programs, but it invalidated others. The court's jurisprudence was muddled and depended on fine distinctions. Nevertheless, it appeared to reflect, in part, the belief that government and religion should be confined to their own, separate realms, thereby protecting the autonomy and vitality of each. Indeed, in its invalidation of various programs, the court sometimes appeared to adopt a strong and categorical interpretation of its separationist language in Everson, which had declared that the government cannot "pass laws which aid one religion [or] all religions" and that "no tax in any amount, large or small, can be levied to support any

${ }^{58}$ Id. at $698-706$ (Breyer, J., concurring in the judgment). 
religious activities or institutions." 59 During this period, the court also adopted and applied an influential constitutional test, drawn from its I97 I decision in Lemon v. Kurtzman, ${ }^{60}$ which invalidated programs that reimbursed religious schools for various educational expenses. Under this test, a statute (or other governmental action) was required to satisfy each of three requirements: "First, the statute must have a secular legislative purpose; second, its principal or primary effect must be one that neither advances nor inhibits religion ...; finally, the statute must not foster 'an excessive governmental entanglement with religion." ${ }^{\prime}$

The high-water mark of public aid separationism, and, it seems, its last hurrah, was in two 1985 decisions. In School District of Grand Rapids v. Ball ${ }^{62}$ and Aguilar v. Felton ${ }^{63}$ the court, applying the Lemon test, ruled that the Establishment Clause barred publicly paid teachers from providing secular, remedial education on the premises of primary and secondary religious schools. The challenged programs extended to religious and nonreligious schools alike, and the court found that they had the purpose of supporting secular education. Nonetheless, the court concluded that the challenged program in Grand Rapids impermissibly advanced the "sectarian enterprise" of the religious schools because the aid was "direct and substantial." The court also was concerned that the publicly funded teachers might knowingly or unwittingly "conform their instruction to the environment in which they teach" and that the children attending the schools might perceive a "symbolic union of church and state." ${ }^{64}$ In Aguilar, the challenged program included a system of governmental monitoring to ensure that the remedial classes and therefore the aid would remain entirely secular, both in reality and in perception. That very system of monitoring, however, led the court to find an excessive governmental entanglement with religion. In a dissenting opinion that foreshadowed the jurisprudential change that was to follow, then-Justice Rehnquist lamented the "Catch-22" that he believed the court had created. ${ }^{65}$

In the years since I985, the Supreme Court, influenced by the appointment of more conservative justices, has embraced a considerably more relaxed approach in this setting, much as it has adopted a more relaxed interpretation of the Free Exercise Clause. Indeed, the court's free exercise

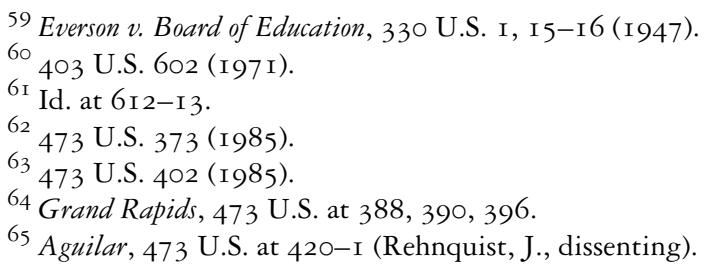


shift, exemplified by Employment Division v. Smith, has been mirrored in the public aid context by a similar emphasis on neutrality as the critical touchstone of constitutional analysis. Accordingly, the court has retreated from its earlier, separationist decisions, ruling that the government generally is free to provide aid to religious beneficiaries under programs that extend "neutrally" to religious and nonreligious recipients alike. In its I 988 decision in Bowen v. Kendrick, ${ }^{66}$ for instance, the court permitted Congress to include religious organizations as grant recipients in a funding program designed to address teenage sexuality, as long as the grants were confined to secular activities.

In Bowen, the court distinguished Grand Rapids and Aguilar, but those decisions were becoming increasingly tenuous. By 1997, the court was prepared to overrule them outright, and so it did in Agostini v. Felton. ${ }^{67}$ In Agostini, the court approved exactly what it had rejected twelve years earlier: the use of publicly paid teachers to provide secular, remedial education at religious schools. Three years later, in Mitchell v. Helms ${ }^{68}$ the court likewise approved a program that provided federally funded computers and other instructional equipment and materials to primary and secondary schools, religious as well as nonreligious, with the amount of aid dependent on the number of students at each school. In so doing, the court overruled additional precedents from the earlier, more separationist period. As the court explained in Agostini, it now is strongly inclined to uphold aid that "is allocated on the basis of neutral, secular criteria that neither favor nor disfavor religion, and is made available to both religious and secular beneficiaries on a nondiscriminatory basis." According to the court, such programs respect religious freedom, if not separation, because they do not "give aid recipients any incentive to modify their religious beliefs or practices" in order to qualify. ${ }^{69}$

The court has been especially approving of neutral funding programs that support religious organizations indirectly, through voucher or similar programs under which aid flows initially to individuals and reaches religious organizations only if individual recipients, as a matter of private choice, elect to use it there. Chief Justice Rehnquist played an influential role in this setting, writing a series of majority opinions that culminated in the court's 2002 school voucher decision. In Zelman v. Simmons-Harris, $7^{\circ}$

\footnotetext{
66 487 U.S. 589 (1988).

${ }_{67} 52$ I U.S. $203,235-6$ (I997).

68530 U.S. 793 (2000).

69 Agostini, 52 I U.S. at 23I, 232.

70536 U.S. 639 (2002).
} 
the court rejected an Establishment Clause challenge to a voucher program that provided substantial tuition support for low-income parents, who could use the support at religious as well as nonreligious schools. The program was formally nondiscriminatory, but more than 90 percent of the vouchers were being used at religious schools. Even so, the court upheld the program, suggesting that nondiscriminatory programs of indirect aid promote religious liberty and are virtually immune from Establishment Clause invalidation, even if individuals disproportionately direct their benefits to religious destinations. As long as a program of indirect aid is neutrally drawn and is "a program of true private choice" that is not "skewed" to favor religious organizations, the court wrote, the program "is not readily subject to challenge under the Establishment Clause." $7^{1}$ The court emphasized that it had never invalidated such a program, and it implied that it never would.

Some constitutional limits remain, at least for now, on direct aid programs. The most important restriction is that direct aid, even under neutrally drawn programs, cannot support religious activities as such. It must be segregated and confined to secular uses. For example, the government can directly provide religious schools with computers and secular textbooks, but it cannot provide them with Bibles. Conversely, this restriction does not apply to indirect aid. As Zelman makes clear, the ultimate destination of indirect aid is beside the point, as long as the program itself is neutral. Thus, there is no need to segregate indirect aid, including the proceeds of vouchers, to uses that are secular in nature.

The court's increasingly permissive stance concerning public aid, both direct and indirect, laid the constitutional groundwork for funding religious organizations that provide social services addressing such problems as poverty, crime, and drug addiction. During the presidency of Bill Clinton, Congress enacted a limited program called "Charitable Choice." The inclusion of religious organizations in social-services funding was expanded and promoted through the "Faith-Based Initiative" of President George W. Bush, and it has continued in a different form with the support of President Barack Obama. A number of states have adopted similar programs. Under prevailing constitutional law, these programs, which extend neutrally to religious and nonreligious groups alike, probably are permissible as long as direct grants are confined to secular services. And Zelman strongly supports the constitutionality of another aspect of these initiatives, the funding of vouchers that recipients can use at providers of their choice, even if some of the providers offer religiously oriented services.

${ }^{7 \mathrm{I}}$ Id. at $649-53$. 


\section{THE FREE EXERCISE CLAUSE AND DISCRIMINATORY FUNDING EXCLUSIONS}

One question left unresolved by Zelman was whether the government even retains the constitutional option of excluding religious organizations from programs of indirect funding for privately provided education or social services. This issue arises not under the Establishment Clause, but under the Free Exercise Clause. As explained earlier, the Supreme Court, despite the restrictive approach of Employment Division v. Smith, has continued to insist that laws targeting religion for discriminatory disadvantage trigger strict free exercise scrutiny and probable invalidation. There was a credible argument that this reasoning would extend to indirect funding programs that discriminate against religion by precluding recipients from choosing religious options. An argument along these lines persuaded the U.S. Court of Appeals for the Ninth Circuit, ${ }^{72}$ but a seven-justice Supreme Court majority, in yet another opinion by Chief Justice Rehnquist, reversed the Ninth Circuit in Locke v. Davey, ${ }^{73}$ decided in 2004.

In Locke, the court considered a State of Washington program that provided scholarships to students at public and private colleges, but that denied the scholarships to otherwise eligible students at religious colleges if they were majoring in devotional theology, typically to prepare for careers in the ministry. The state relied on a provision in Washington's state constitution, which mandated a stronger separation of church and state than that required by the First Amendment. Declaring that there is room for "play in the joints" between the Establishment and Free Exercise Clauses, ${ }^{74}$ the Supreme Court permitted the state's antiestablishment policy to prevail. The court asserted that the burden on religious exercise was relatively minor, and it rejected strict scrutiny in favor of a far more lenient balancing approach. Under that approach, the state's denial of funding was justified by historical antiestablishment concerns about taxpayer-supported clergy, concerns that were reflected in a number of state constitutions. Read narrowly, Locke might be limited to the selective denial of funding for the devotional religious work and training of clergy and other religious professionals. Conversely, and perhaps more likely, it might permit the government to exclude religious beneficiaries in other contexts as well, including voucher programs of all sorts. If so, then Zelman and Locke, taken together, leave the inclusion or exclusion of religious beneficiaries largely to the discretion of Congress and the states.

\footnotetext{
72 Davey v. Locke, 299 F.3d 748 (9th Cir. 2002), rev'd, 540 U.S. 7 I 2 (2004).

73540 U.S. 7 I 2 (2004).

${ }^{74}$ Id. at 7 I 8.
} 


\section{RELIGION, LAW, AND POLITICS}

This essay has focused on religion's direct interaction with government and law in the contemporary period, especially in connection with First Amendment and related legal claims. More broadly, religion has played an important role in other political and legal developments, many of which are discussed elsewhere in this volume. In the presidential election of I960, Americans for the first time elected a Roman Catholic, John F. Kennedy. Another progressive achievement, the Civil Rights Act of 1964, was inspired by the religious vision of Martin Luther King, Jr. More recently, in part as a reaction to the Supreme Court's 1973 decision in Roe v. Wade, 75 religion has been a prominent feature in conservative politics. Courted strongly by Ronald Reagan and later Republican leaders, religious conservatives have become an important constituency in the Republican Party. They have worked to undo the Supreme Court's protection of abortion rights, have protested the destruction of embryos for stem cell research, and have resisted the movement toward same-sex marriage. Even so, progressive religious voices have not disappeared, and Democratic candidates and officials, including President Barack Obama, have made notable appeals for religious support.

These broader political and legal developments are not entirely disconnected from the First Amendment. Much to the contrary, that amendment, as construed by the Supreme Court, sets the outer boundaries of religious politics. In the contemporary period, the court has precluded the adoption of certain governmental policies, including school prayer and starkly promotional religious symbolism. By contrast, the court increasingly has declared other issues a matter of political choice. Generally speaking, it has ruled that the government may, but need not, protect religious conduct from nondiscriminatory laws, and that the government may, but need not, include religious beneficiaries in broader funding programs. At the same time, the court has strongly protected private religious speech, no less than political speech, and it has shown no inclination to confine the role of religious advocacy on political issues.

At present, the First Amendment's constraints on religion-related policy making are relatively limited, at least as compared to those imposed by the court from the I960s to the I980s. But the justices have been deeply divided in many of their recent decisions. Moreover, as the history of the last half-century reveals, the Supreme Court's positions are not static. The court responds to political and cultural changes even as its decisions themselves influence those developments. This cycle of change is certain to continue.

75 4 IO U.S. II3 (I973). 


\section{SUGGESTIONS FOR FURTHER READING}

Conkle, Daniel O. Constitutional Law: The Religion Clauses. 2nd ed. New York, 2009 .

Dierenfield, Bruce J. The Battle over School Prayer: How Engel v. Vitale Changed America. Lawrence, KS, 2007.

Jeffries, John C., and James E. Ryan. "A Political History of the Establishment Clause." Michigan Law Review IO० (200I): 279-370.

Laycock, Douglas. "Church and State in the United States: Competing Conceptions and Historic Changes," Indiana Journal of Global Legal Studies I3 (2006): $503-4 \mathrm{I}$.

Lupu Ira C., and Robert W. Tuttle. "The Faith-Based Initiative and the Constitution." DePaul Law Review 55 (2005): I-I I 8.

McConnell, Michael W., John H. Garvey, and Thomas C. Berg. Religion and the Constitution. 2nd ed. New York, 2006.

Symposium "Religious Liberty at the Dawn of a New Millennium." Indiana Law Journal 75 (2000): I-332.

"The Religion Clauses in the 2 Ist Century." West Virginia Law Review I IO (2007): i-vii, I-544. 